\title{
Atmospheric and hydrological boundary conditions for slushflow initiation due to snowmelt
}

\author{
Dieter Scherer, ${ }^{1}$ Martin Gude, ${ }^{2}$ Markus Gempeler, ${ }^{1}$ Eberhard Parlow ${ }^{1}$ \\ ${ }^{1}$ MCR Laboratory University of Basel, Spalenring 145, CH-4055 Basel, Switzerland \\ ${ }^{2}$ Department of Geography, University of Jena, Löbdergraben 32, D-07740 Jena, Germany
}

\begin{abstract}
Slush-flows of a large variety of magnitudes were observed during three field campaigns to Liefdefjorden, northwestern Spitsbergen, and one campaign to Kärkevagge, northern Sweden. In the latter campaign, the release and movement of a slush torrent was documented on video and in photographs. Meteorological and snow-hydrological measurements carried out during these campaigns were analysed with respect to slushflow initiation due to snowmelt.

Since slushflows are quite common in polar and sub-polar drainage basins (although they are not restricted to these regions), specific atmospheric and hydrological boundary conditions must be fulfilled for slushflow initiation due to snowmelt. Radiative fluxes, air temperatures and wind velocities are the most important atmospheric variables, while snow depth, depth of the water-saturated layer, hydraulic conductivity and snow structure are the primary snow variables of interest.

It has been shown that slushflows can be released due to energy input in the snow cover by net radiation and sensible heat within the ordinary range of the high-latitudinal snowmelt period. Slush torrent initiation is intensified by a superposition of both energy fluxes. Infiltration losses were not significant even when permafrost was not present. Crucial for slushflow initiation due to snowmelt is the timing of energy input and meltwater flow through the snowpack.
\end{abstract}

\section{INTRODUCTION}

One of the first scientific reports on slushflows was given by Washburn and Goldthwait (1958). Since then, only a relatively limited number of studies have been published. During the last years, slushflow research has been stimulated by direct observations of large events by scientists (Barsch and others, 1993, 1994; Scherer, 1994; Scherer and Parlow, 1994; Gude and Scherer, 1995). A short review of slushflow research has been given by Gude and Scherer (1995) and is not repeated here. Moreover, one of the most important questions arising from the catastrophic magnitudes reached by some slush torrents, which are the highmagnitude/low-frequency variant of slushflows (cf. Barsch and others, 1993; Gude and Scherer, 1998) is their predictability. The construction of a prognostic slushflow model requires a solid physical basis for the initiation mechanism. It is important to mention that slushflows are frequently released by intense or long-lasting rainfalls as Hestnes (1985) or Hestnes and others (1994) have shown. Rainfall-triggered processes are not in the scope of this study.

One of the most important results of the Kärkevagge field campaign in the spring of 1995 (Gude and Scherer, 1995) was proof of the hypothesis that slushflows occurring during periods of intense snowmelt are primarily released due to the hydraulic gradient evolving from an increasingly inclined meltwater table within the snow cover (cf. Gude and Scherer, 1998). A video taken of the release of a slush torrent on 3 June 1995 in the Kärkerieppe cirque clearly de- monstrated the dominant role of meltwater accumulation in slushflow initiation. Figure 1 shows a photograph of the frontal wave of this slush torrent, which was followed by successive slush waves, typical features of slush torrents. The video and photographs of that slush torrent stress the extremely unsteady flood-wave character of the process. Both documents show that high amounts of water are prerequisite to enable the process.

In this context, some general aspects of atmospheric and hydrological boundary conditions for slushflow initiation due to snowmelt are discussed below.

\section{STUDY SITES}

Two study sites were selected for the investigations. A small drainage basin (Kvikkåa), of $5 \mathrm{~km}^{2}$ size, was intensively studied during three field campaigns to Liefdefjorden, northwestern Spitsbergen (almost $80^{\circ} \mathrm{N}$ ) in the spring and summer months of 1990-1992 (SPE'90-92). In each year, slushflows occurred between 5 and 14 June, despite different meteorological conditions. On 11 June 1992, several slush torrents could be observed in the Liefdefjord region. A detailed description of this study site and the events of 1992 have been given by Barsch and others (1993), Scherer (1994) and Scherer and Parlow (1994).

The second study area is located in the northern Swedish mountains at almost $70^{\circ} \mathrm{N}$. The Kärkevagge valley bottom has an elevation of $700 \mathrm{~m}$ a.s.l., while the release 
zone of the slush torrent observed on 3 June 1995, is situated in a small cirque (Kärkerieppe) at almost $1000 \mathrm{~m}$ a.s.l. The Kärkevagge area has been well-investigated (e.g. Rapp, 1960, 1995; Nyberg, 1985, 1989; Schlyter and others, 1993); the Kärkerieppe study site and instrument set-up of the field campaign in the spring of 1995 has been documented by Gude and Scherer (1995).

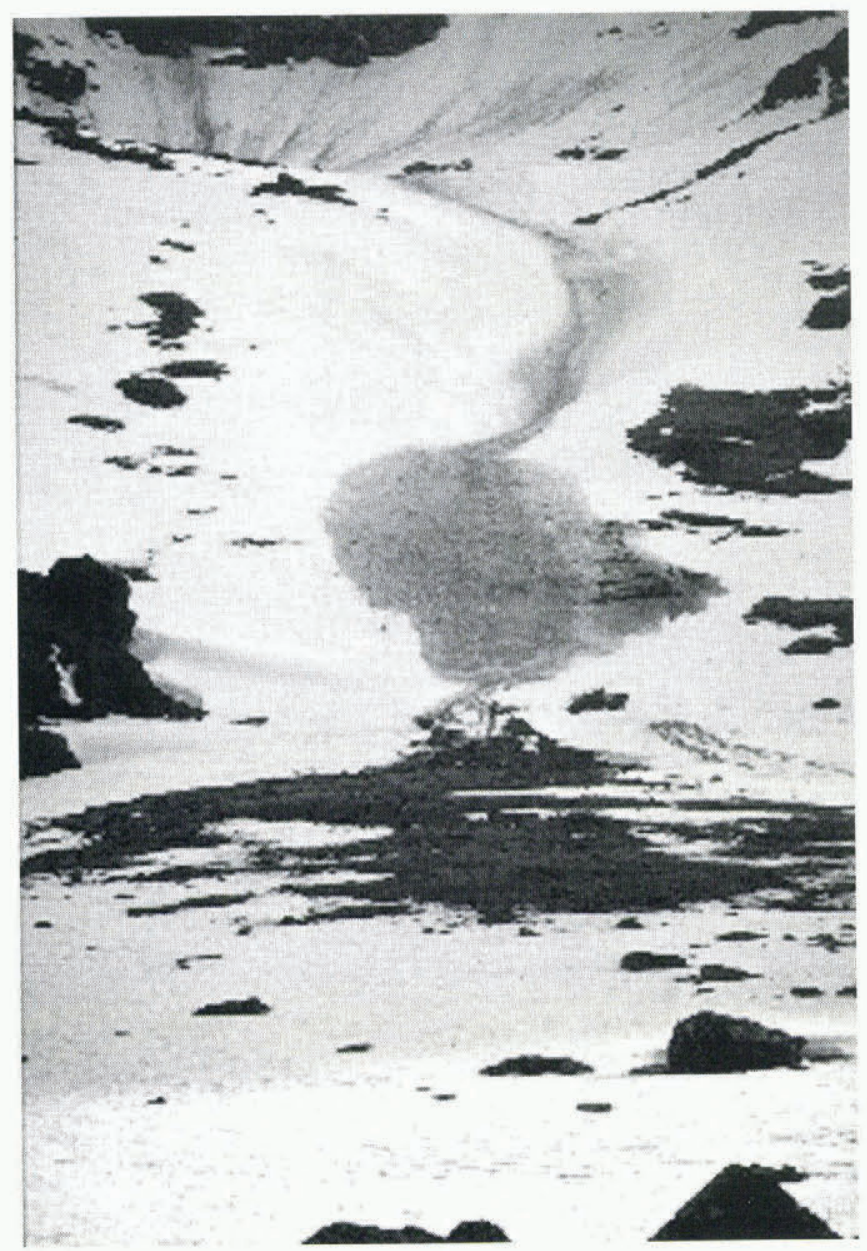

Fig. 1. Slush torrent of 3 June 1995 released in the Kärkerieppe cirque, Kärkevagge, northern Sweden.

\section{METHODS}

Field measurements of meteorological and snow-hydrological variables were analysed to determine meltwater production rates and snowpack-meltwater flow velocities. The latter aspect has been discussed in detail by Gude and Scherer (1998). Significant meltwater production occurs under isothermal snow conditions, i.e. when the total snowpack has reached $0^{\circ} \mathrm{C}$. After this time, the total energy input into the snow cover is available for snowmelt. Storage heat fluxes into or from the soil or rock layer can be neglected. Radiative fluxes were measured with pyranometers (Kipp \& Zonen CM11) and pyrradiometers (Schenk 8111) at several sites. This configuration enabled determination of all components of the radiation budget, including net radiation with an accuracy of $\pm 10 \mathrm{~W} \mathrm{~m}^{-2}$. Turbulent-heat fluxes were measured directly using eddy-covariance systems (Gill ultrasonic anemometers, combined with fast thermocouples and hygrometers) operating at frequencies up to $21 \mathrm{~Hz}$. Turbulent-heat fluxes were also determined from vertical profiles rg/10.3189/1998AoG26-1-377-380 Published online by Cambridge University Press of air temperature, humidity and wind velocity. The accuracy of these measurements was $\pm 15 \mathrm{~W} \mathrm{~m}^{-2}$.

\section{RESULTS}

\section{Meteorology}

The occurrence of small slushflows in the Kvikkåa basin on 14 June 1991 showed that snowmelt solely due to energy input by net radiation can be sufficient to initiate minor events. Over a period of 72 hours prior to those slushflows, the average flux density was $65 \mathrm{~W} \mathrm{~m}^{-2}$ (Scherer, 1994), corresponding to $50 \mathrm{~mm}$ of meltwater production.

Prior to the slush torrents observed in 1992 in northwestern Spitsbergen and 1995 in northern Sweden, meltwater production rates had been much higher, since both net radiation and sensible-heat flux contributed to the energy available for snowmelt. Table 1 summarizes the energy-balance conditions measured at the main meteorological station of the three field campaigns at Liefdefjorden. The station is located $15 \mathrm{~m}$ a.s.l. near the outlet of the Kvikkåa basin. The meltwater-production rate was more than three times higher during the period prior to slushflow release compared to 1991. In particular, high values of sensible-heat flux due to air temperatures up to $13.9^{\circ} \mathrm{C}$ and wind velocities of more than $10 \mathrm{~m} \mathrm{~s}^{-1}$ were responsible for $80 \mathrm{~mm}$ of meltwater production within 34 hours. Latent-heat flux did not contribute significantly to snowmelt.

Table 1. Energy-balance components during the 34 hours prior to the slush torrent at 16.00 CESTon 11 June 1992 in the Kvikkåa drainage basin. SWE indicates snow water equivalent

\begin{tabular}{lcccc}
\hline & $\begin{array}{c}\text { Net } \\
\text { radiation }\end{array}$ & $\begin{array}{c}\text { Sensible } \\
\text { heat }\end{array}$ & $\begin{array}{c}\text { Latent } \\
\text { heat }\end{array}$ & $\begin{array}{c}\text { Snow- } \\
\text { melt }\end{array}$ \\
\hline Mean flux $\left(\mathrm{W} \mathrm{m}^{-2}\right)$ & 86 & 126 & 8 & 220 \\
Total flux $\left(\mathrm{MJ} \mathrm{m}^{-2}\right)$ & 10.5 & 15.4 & 1.0 & 27.0 \\
Mean SWE $\left(\mathrm{mm} \mathrm{d}^{-1}\right)$ & 22.2 & 32.6 & 2.1 & 57.0 \\
Total SWE (mm) & 31.5 & 46.2 & 3.0 & 80.7 \\
\hline
\end{tabular}

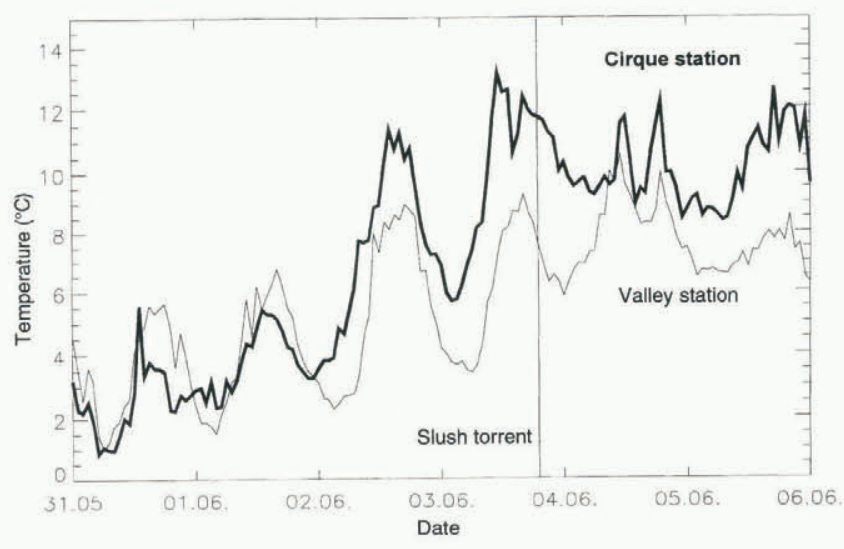

Fig. 2. Hourly averages of air temperatures at the meteorological stations during a period of intense snowmelt in the Kärkevagge, 1995.

The measurements during the Kärkevagge field campaign in the spring of 1995 showed that periods of intense snowmelt are partly accompanied by strong decoupling effects in the boundary layer. Figures 2 and 3 present air 
temperatures and wind velocities at two stations in the Kärkevagge study site. The first station (valley station, $710 \mathrm{~m}$ a.s.l.) was located on a flat area at the main valley bottom, whereas the second one (cirque station, $980 \mathrm{~m}$ a.s.l.) was in the centre of the Kärkerieppe cirque. Prior to the slush-torrent release on the evening of 3 June 1995, this study site was almost completely covered by snow.

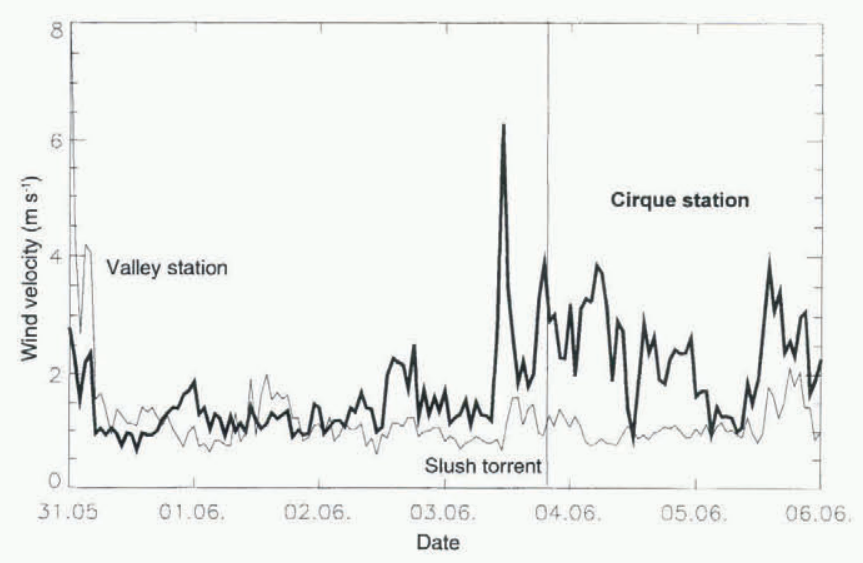

Fig. 3. Hourly averages of wind velocities at the meteorological stations during a period of intense snowmelt in the Kärkevagge, 1995.

Despite the short distance between both stations $(1 \mathrm{~km}$ horizontal, $270 \mathrm{~m}$ vertical), air temperatures differed more than $5 \mathrm{~K}$ with higher values in the cirque area, where the slush torrent was released.

In contrast to the events on 11 June 1992, in the Liefdefjord region, the Kärkevagge slush torrent was not released during extreme weather conditions. Nevertheless, warm-air advection took place, which strongly affected the higher-cirque area, where the slush torrent was released. Figures 2 and 3 demonstrate that critical meteorological conditions can lead to a high spatial variability of the energy balance even in small drainage basins. A spatially distributed treatment of the atmospheric variables is probably required for a prognostic model that could be applied for risk-assessment purposes or forecasting tasks.

Both slush torrents were released while snowmelt was driven by net radiation in combination with the sensibleheat flux. Sensible-heat flux is important, since net radiation is limited by astronomical factors and by snow albedo, which was higher than $65 \%$ in both cases.

High meltwater-production rates leading to $50-80 \mathrm{~mm}$ meltwater production within a few days was shown to be essential for the initiation of slush torrents. However, even such high melt rates are not able to generate water-saturated layers up to several meters thick as observed in Kärkevagge solely from local snowmelt. Meltwater flow through the snowpack is the link between the meteorological conditions and slushflow release.

\section{Snow hydrology}

Snow-hydrological conditions are not only dependent on meteorological conditions but also on terrain features in the initiation area and the adjacent slopes. The basic correlation between topography and snow processes is stressed by a comparative analysis of the investigated processes in northwestern Spitsbergen and northern Sweden. Despite the fact that the Kvikkåa basin is more than $1000 \mathrm{~km}$ closer to the North Pole, both regions show many similarities:

Snowmelt is concentrated in one pronounced period starting in late-May and lasting approximately 1 month. Onset of snowmelt was delayed 1 or 2 weeks in the Kvikkåa basin compared to the Kärkevagge basin during the years of the investigations.

During the main snowmelt period, solar irradiance may occur 24 hours per day.

Slushflow release zones are situated in gently inclined sections of valleys, which are part of the fluvial system during the summer.

In close proximity to the release zones, the up-slope area includes steeper slopes of significant extent.

There are several hydrological implications resulting from these similarities.

A snow cover of at least $40-50 \mathrm{~cm}$ depth must be present, when solar irradiance is close to its annual maximum. Despite the high solar albedo of snow, higher values of solar irradiance will successively lead to an increasing energy input by net radiation into the snow cover. During the same period, the probability of warm air advection is increased. Both factors are needed for a superposition of high values of net radiation and sensible-heat flux.

Interruption of meltwater production or refreezing of meltwater during the night should not occur significantly within the snowpack. These processes have two stabilizing effects. On the one hand, they cause a certain delay of the meltwater production during day-time. Also, the distance that meltwater can pass by flowing through the snowpack is shortened.

Meltwater flow concentrates in the valley bottoms. On steeper slopes, drainage conditions are usually sufficient to prevent meltwater accumulation due to the higher hydraulic gradients compared to gently inclined sections.

Steep and extended slopes adjacent to the slushflow release zone are favorable topographic situations, particularly for slush torrents, since the typical duration of an intense snowmelt period is only a few days. Meltwater produced during such periods must be able to flow through the snow to reach these areas, where convergence takes place. Considering meltwater-flow velocities of less than $1 \mathrm{~m} \mathrm{~h}^{-1}$ in the beginning and $20-40 \mathrm{~m} \mathrm{~h}^{-1}$ as an upper limit of snowpack, meltwater-flow velocity under saturated conditions at slopes (cf. Gude and Scherer, 1998), it is obvious that the maximum distance between meltwater production and accumulation is limited. Assuming a high upper limit of the average velocity of $20 \mathrm{~m} \mathrm{~h}^{-1}$ and a duration of the snowmelt event of $50 \mathrm{~h}$, meltwater could pass a distance of $1 \mathrm{~km}$. This demonstrates that a maximum distance of about $1 \mathrm{~km}$ could be used for determining the catchment area of a slushflow release zone.

Slushflows are frequently released in terrain situations with confluent meltwater pathways (cf. Nyberg, 1985). It is possible to identify these critical areas by a digital morphometric analysis. However, confluence is an insufficient condition for slushflow release. Due to the distributed nature of meltwater production and drainage through the snow matrix, meltwater flow has to converge to generate an inclined water table. High rates of meltwater convergence are only possible as long as the bulk hydraulic conductivity 
of the snow cover is small, at least in the release zone. Otherwise, the outflux of meltwater at a given vertical snow column would not be overcompensated by the influx. Areas of convergent meltwater flow can mainly be observed in valley bottoms of gentle slope angles prior to the onset of channelled runoff.

Significant infiltration losses would prevent meltwater accumulation. In polar and sub-polar drainage basins, there are several factors reducing infiltration of meltwater in the sub-layer.

Frozen ground usually acts as an effective impermeable layer, either by a very low hydraulic conductivity or by causing basal refreezing of meltwater. If permafrost conditions prevail, the sub-layer is frozen as long as snow is present. In polar and sub-polar regions, the sub-layer is usually frozen during snowmelt, even when permafrost is not present.

Many drainage basins are characterized by weakly developed or an absence of soils. Impermeable rock layers can substitute frozen ground as inhibitor of infiltration losses.

\section{GONGLUSIONS}

Slushflows can be released due to energy input in the snow cover by net radiation and sensible heat within the ordinary range of a high-latitudinal snowmelt period. Sensible heat flux is particularly important for slush-torrent initiation, since it is not limited by external factors as is the case for net radiation. A superposition of high net radiation and sensible-heat flux is most favorable for high-magnitude events.

With respect to slushflow initiation due to snowmelt, infiltration losses can be disregarded at high latitudes, even when permafrost is not present. This explains why slushflows are not restricted to permafrost areas.

Crucial for slushflow initiation, due to snowmelt, is the timing of energy input and meltwater flow through the snowpack. Gently sloping sections with confluent meltwater paths in valley bottoms and steeper slopes in the adjacent up-slope area are well-disposed for slush-torrent initiation. The distance between meltwater production and accumulation is limited by the duration of the intense snowmelt period and by the velocity of the meltwater flow through the snowpack.

\section{ACKNOWLEDGEMENTS}

We wish to express our thanks to all those who have helped us to obtain these results, particularly to D. Barsch, W.-D. Blümel, G. Bing, T. Löschmann, R. Mäusbacher, A. Rapp, N. Ritter, A. Schulte, G. Schukraft and F. Siegrist. The Abisko Scientific Research Station has supported our research in the Kärkevagge logistically. Projects contributing to these results were financially supported by the Swiss National Science Foundation, the German Science Foundation and the Swiss Academy of Science.

\section{REFERENCES}

Barsch, D., M. Gude, R. Mäusbacher, G. Schukraft, A. Schulte and D. Strauch. 1993. Slush stream phenomena - process and geomorphic impact. Z Geomorphol., Supplementband 92, 39-53.

Barsch, D., M. Gude, R. Mäusbacher, G. Schukraft and A. Schulte. 1994 Recent fluvial sediment budgets in glacial and periglacial environments, NW Spitsbergen. Z. Geomorphol., Supplementband 97, 111-122.

Gude, M. and D. Scherer. 1995. Snowmelt and slush torrents - preliminary report from a field campaign in Kärkevagge, Swedish Lappland. Geogr. Ann., 77A (4), $199-206$.

Gude, M. and D. Scherer. 1998. Snowmelt and slushflows: hydrological and hazard implications. Ann. Glaciol., 26 (see paper in this volume).

Hestnes, E. 1985. A contribution to the prediction of slush avalanches. Ann. Glaciol., 6, 1-4.

Hestnes, E., S. Bakkehøi, F. Sandersen and L. Andresen. 1994. Weather and snowpack conditions essential to slushflow release and downslope propagation. In ISSW'94. International Snow Science Workshop, 30 October-3 November 1994, Snowbird, Utah. Proceedings. Snowbird, UT, P.O. Box 49, $40-57$.

Nyberg, R. 1985. Debris flows and slush avalanches in northern Swedish Lappland-distribution and geomorphological significance. Medd. Lunds Univ. Geogr. Inst. Avh. 97.

Nyberg, R. 1989. Obervations on slushflows and their geomorphological effects in the Swedish mountain area. Geogr. Ann., 71A (3-4), 185-198.

Rapp, A. 1960. Recent development of mountain slopes in Kärkevagge and surroundings, northern Scandinavia. Geogr. Ann., 42 (2-3), 65-200.

Rapp, A. 1995. Case studies of geoprocesses and environmental change in mountains of northern Sweden. Geogr. Ann., 77A(4), 189-198.

Scherer, D. 1994. Slush stream initiation in a High Arctic drainage basin in NW-Spitsbergen. Stratus (Basel), 1.

Scherer, D. and E. Parlow. 1994. Terrain as an important controlling factor for climatological, meteorological and hydrological processes in NWSpitsbergen. Z. Geomorphol., Supplementband 97, 175-193.

Schlyter, P. and 6 others. 1993. Geomorphic process studies related to climate change in Kärkevagge, northern Sweden - status of current research. Geogr. Ann., 75A(1-2), 55-60.

Washburn, A.L. and R.P. Goldthwait. 1958. Slushflows. [Abstract.] Geol. Soc. Am. Bull., 69, 1657-1658. 